\title{
KETELADANAN SOSIAL DALAM FILM YO WIS BEN 1 KARYA BAYU SKAK, BAGUS BRAMANTI, DAN GEA REXY
}

\author{
Ratmiati $^{1}$, Suci Larassaty ${ }^{2}$, Khadijah Ramadhanti ${ }^{3}$ \\ ${ }^{1}$ Institut Agama Islam Negeri Batusangkar \\ ${ }^{2}$ Universitas Muhammadiyah Prof. Dr. Hamka \\ ${ }^{3}$ Universitas Negeri Padang ${ }^{3}$ \\ Email: ratmiati@iainbatusangkar.ac.id ${ }^{1}$, sucilarassaty@gmail.com ${ }^{2}$, \\ dijahramadhan@gmail.com ${ }^{3}$
}

\begin{abstract}
Abstrak: Krisis keteladanan sosial potensial menimbulkan berbagai konflik dalam kelompok masyarakat. Tujuan penelitian ini adalah mendeskripsikan bentuk keteladanan nilai-nilai sosial dalam naskah skenario film Yo Wis Ben 1 karya Bayu Skak, Bagus Bramanti, dan Gea Rexy sebagai upaya pembentukan nilai karakter bagi siswa khususnya siswa SMA. Metode penelitian yang digunakan dalam mengkaji naskah skenario film Yo Wis Ben 1 karya Bayu Skak, Bagus Bramanti, dan Gea Rexy ini adalah metode kualitatif deskripstif. Objek penelitian ini adalah nilai-nilai sosial dalam naskah skenario film Yo Wis Ben 1 karya Bayu Skak, Bagus Bramanti, dan Gea Rexy. Teknik pengumpulan data dalam penelitian ini menggunakan teknik pustaka, simak, dan catat. Hasil penelitian ini menunjukkan bahwa nilai-nilai sosial yang terdapat dalam naskah skenario film Yo Wis Ben 1 karya Bayu Skak, Bagus Bramanti, dan Gea Rexy meliputi nilai hubungan sosial, tanggung jawab, kasih sayang, loyal, serta rela berkorban dan memberikan partisipasi dalam kehidupan sosial. Serta implikasi nilai-nilai sosial dalam naskah skenario film Yo Wis Ben 1 karya Bayu Skak, Bagus Bramanti, dan Gea Rexy sebagai pembentuk nilai karakter siswa SMA karena karya sastra ini menceritakan kehidupan yang sangat dekat dengan siswa SMA. Keteladanan yang tergambar melalui nilai-nilai sosial tersebut menjadi awal terbentuknya jiwa karakter siswa, memberikan partisipasi dalam kehidupan sosial dalam bermasyarakat.
\end{abstract}

Kata Kunci: keteladanan, naskah film, nilai sosial.

\section{EXAMPLARY OF SOCIAL VALUES IN YO WIS BEN 1 FILM BY BAYU SKAK, BAGUS BRAMANTI, AND GEA REXY}

\begin{abstract}
The crisis of social modeling has the potential to cause various conflicts in community groups. The purpose of this study is to describe the form of exemplary social values in the screenplay of the film Yo Wis Ben 1 by Bayu Skak, Bagus Bramanti, and Gea Rexy as an effort to build character values for students, especially high school students. The research method used in reviewing the screenplay of the film Yo Wis Ben 1 by Bayu Skak, Bagus Bramanti, and Gea Rexy is a descriptive qualitative method. The object of this research is the social values in the screenplay of the film Yo Wis Ben 1 by Bayu Skak, Bagus Bramanti, and Gea Rexy. Data collection techniques in this study used library, listen, and note-taking techniques. The social values contained in the screenplay of the film Yo Wis Ben 1 by Bayu Skak, Bagus Bramanti, and Gea Rexy, are the values of social relations, responsibility, affection, loyalty, and being willing to sacrifice and provide participation in social life. As well as the implications of social values in the screenplay of the film Yo Wis Ben 1 by Bayu Skak, Bagus Bramanti, and Gea Rexy as forming the character values of high school students because this literary work tells the life that is very close to Exemplary High School students which is illustrated through social values. This is the beginning of the formation of students' character souls provide participation in social life in society.
\end{abstract}

Keywords: exemplary, film scripts, social values.

BASASTRA Jurnal Bahasa, Sastra, dan Pengajarannya

Volume 9 Nomor 2, Oktober 2021, P-ISSN 2302-6405, E-ISSN 2714-9765 


\section{PENDAHULUAN}

Era modern ini diidentikkan dengan era masyarakat digital. Setiap aktivitas manusia akan digerakkan melalui serangkaian teknologi digital. Teknologi ini dioperasikan dengan menekan beberapa digit (angka) yang disusun dengan berbagai urutan. Relasi yang terbangun di antara individu adalah relasi pertukaran digital, setiap manusia hanya melakukan serangkaian transaksi atau interaksi melalui simbol-simbol digital. Interaksi antarmanusia digerakkan dengan teknologi serba digital: komputer, internet, telepon, smartphone atau bisa disebut dengan gawai (Martono, 2016).

Adapun perkembangan teknologi secara cepat telah membawa dunia memasuki era globalisasi yang serba maju dan modern. Pada zaman yang serba modern ini, manusia dituntut agar mengikuti perkembangan zaman dimana kehidupan menjadi serba praktis, efektif, dan efisien. Hal ini dikarenakan kebutuhan hidup yang semakin banyak dan semakin kompleks. Oleh karenanya, diciptakan alat-alat yang dapat membantu kelancaran dan meringankan beban pekerjaan manusia salah satunya teknologi yang sangat populer adalah gawai.

Penggunaan gawai dapat memberikan efek positif dan efek negatif kepada para penggunanya. Salah satu contoh dampak positif yaitu memberikan kemudahan kepada para pengguna gawai untuk berkomunikasi tanpa mengeluarkan biaya yang mahal dan tidak membutuhkan waktu yang lama.

Tetapi, tidak semua penggunaan gawai berdampak positif, di sisi lain gawai juga memberikan dampak yang negatif kepada para penggunanya. Salah satu contoh yang konkret, di era modern ini terkadang manusia lupa akan hakikatnya sebagai makhluk sosial yaitu makhluk yang membutuhkan orang lain.

Berkaca pada kondisi saat ini, era globalisasi di mana teknologi semakin canggih serta banyak kemudahan terdapat di dalamnya, hal ini dapat dirasakan langsung oleh para siswa yang mau tidak mau harus menggunakan teknologi informasi guna mengikuti pembelajaran jarak jauh akibat covid-19. Namun kemajuan teknologi itu juga memberi dampak negatif terhadap para siswa. Intensitas penggunaan gawai guna mengakses informasi yang cenderung meningkat, lama-kelamaan mengakibatkan penurunan sikap sosial terhadap lingkungan sendiri. Siswa lebih memilih menghabiskan waktu berjam-jam menggunakan teknologi komunikasi dibanding mengobrol dengan orang tua, kakak, adik, sahabat di ruang keluarga maupun sekadar menjalin komunikasi dengan temanteman di dunia maya. Saat ini siswa membutuhkan contoh nyata, sebuah keteladanan yang mengandung nilai sosial agar degradasi nilai sosial siswa akibat covid-19 tidak semakin jauh merosot. 
Penggunaan gawai dalam kehidupan sehari-hari tidak hanya memengaruhi perilaku orang dewasa, anak-anak pun tidak luput dari pengaruh penggunaan gawai salah satunya dalam kemampuan interaksi sosial (Febrina, 2018).

Kehidupan sosial dan budaya masyarakat sangat berperan dalam sebuah karya sastra. Menikmati karya sastra hakikatnya seperti membaca kehidupan, karena itu secara langsung maupun tidak langsung nilai dan pesan yang dikandungnya dapat terefleksi dalam diri penikmatnya. Melalui perantara media film, penyampaian pesan moral dan nilai karakter lebih mudah tersampaikan. Salah satu jenis pendidikan yang harus diberikan kepada manusia adalah pendidikan karakter (Munawwaroh, A. 2019).

Banyak hal yang dapat dilakukan dalam upaya menanamkan nilai sosial pada siswa yang telah terbiasa dengan kecanggihan teknologi saat ini. Sebanyak 10 persen masyarakat Indonesia gemar membaca dan 90 persen penduduk gemar nonton televisi dan tidak suka membaca (Sularsih, 2015). Berdasarkan hal tersebut, penanaman nilai-nilai karakter bisa melalui film.

Peran film bagi nilai sosial dan karakter tidak terlepas dari naskah skenario yang baik oleh sineas. Sebuah naskah film Indonesia karya oleh Bayu Skak, Bagus Bramanti, dan Gea Rexy dengan judul Yowis Ben 1 karya tiga anak muda Indonesia yang mengangkat budaya Jawa dan kehidupan sosial di Jawa Timur. Berlatar kehidupan anak sekolah yang disajikan dengan menggunakan $80 \%$ bahasa daerah dan 20\% bahasa Indonesia.

Film "Yowis Ben 1" merupakan karya sastra populer yang sangat dekat dengan kehidupan masyarakat Jawa Timur. Ada kesamaan karakter dan kehidupan sosialnya dengan kehidupan masyarakat di Indonesia bagian lain. Hanya saja, pada film ini memiliki kekentalan nilai karakter dan tingkah laku remaja di sekolah dalam menemukan jati dirinya. Nilai sosial merupakan nilai tertinggi berupa kasih sayang antara manusia (Zakiyah dan Rusdiana (2014: 20).

Nilai sosial yang membentuk karakter tokoh siswa Indonesia tergambar dalam tokoh-tokoh aktor dalam naskah film ini, yaitu: Bayu yang diperankan Bayu Skak, Doni yang diperankan oleh Joshua Suherman, Yayan diperankan Tutus Thomson, dan Nando yang diperankan Brandon Salim. Mereka adalah empat orang siswa yang mencari jati diri dan memiliki latar kehidupan yaang berbeda-beda dalam segi ekonomi, pendidikan orang tua, dan masalah kepribadian dirinya.

Proses penanaman pendidikan karakter yang terencana mampu mengembangkan potensi diri sehingga menghasilkan manusia yang berkarakter dan beradab (Chriszia, D. (2020). Pendidikan bukan hanya memberi pengetahuan melainkan juga sebagai sarana untuk menyalurkan 
nilai-nilai kehidupan dalam bermasyarakat (Mitaviana, A. G., 2020).

Pendidikan karakter adalah segala usaha yang dilakukan oleh pendidik untuk membentuk karakter peserta didik (Supranoto, 2015). Dalam pendidikan karakter, keteladanan diperlukan dalam setiap lingkungan pendidikan, yakni lingkungan keluarga, sekolah, dan masyarakat. Di lingkungan keluarga, keteladanan orang tua sangat diperlukan dalam pendidikan karakter. Munawwaroh, A. (2019). Anak yang memiliki pengetahuan karakter, perasaan karakter, dan tindakan karakter yang rendah disebabkan oleh keteladanan orang tua yang rendah dalam ketiga aspek tersebut (Novita, 2015).

Keteladanan sebagai metode pendidikan karakter dapat digunakan untuk mengidentifikasi faktor penyebab baik-buruknya karakter seseorang (Banks, 2009). Misalnya, jika peserta didik tidak memiliki karakter peduli lingkungan, Peran keteladanan orang tua di lingkungan orang tua amat menentukan keberhasilan pendidikan karakter di lingkungan sekolah dan lingkungan masyarakat. Dengan demikian, untuk mempermudah pencapaian pendidikan karakter pada peserta didik, sekolah harus bekerja sama dengan orang tua (Saripah, 2016). Keteladanan sebagai metode pendidikan karakter tidak hanya harus ditunjukkan oleh pendidik di lingkungan keluarga, sekolah, dan masyarakat, tetapi juga harus ditunjukkan oleh teman sebaya dan media massa (Wening, 2012).

Keteladanan membutuhkan komprehensivitas atau kesatupaduan antara pendidik di berbagai lingkungan, baik lingkungan keluarga, sekolah, maupun masyarakat (Cahyaningrum, 2017).

Tujuan penelitian ini adalah mendeskripsikan keteladanan nilainilai sosial dalam naskah film Indonesia karya oleh Bayu Skak, Bagus Bramanti, dan Gea Rexy dengan judul Yowis Ben 1 sebagai upaya pendekatan untuk membentuk nilainilai karakter dalam diri siswa

\section{METODE}

Metode yang digunakan dalam penelitian ini adalah kualitatif deskriptif. Menurut Moleong, (2014:4) metode kualitatif adalah prosedur penelitian yang menghasilkan data deskriptif berupa kata-kata tertulis atau lisan dari orangorang dan perilaku yang diamati.

Sumber data dalam penelitian ini adalah naskah skenario film $Y o$ Wis Ben 1 karya Bayu Skak, Bagus Bramanti, dan Gea Rexy. Data penelitian ini adalah kalimat-kalimat ataupun ujaran-ujaran yang mengandung nilai-nilai sosial.

Teknik pengumpulan data dalam penelitian ini adalah teknik studi pustaka. Studi pustaka dilakukan untuk mendapatkan bahan-bahan dan informasi yang berhubungan dengan penelitian seperti buku-buku, artikel, 
dokumen-dokumen lain yang berhubungan dengan penelitian.

Langkah-langkah analisis data yang digunakan dalam penelitian ini yaitu: (1) Membaca dan memahami naskah skenario film Yo Wis Ben 1 karya Bayu Skak, Bagus Bramanti, dan Gea Rexy. (2) Mendeskripsikan fakta cerita yang berkaitan dengan nilai sosial yang terdapat dalam naskah skenario film Yo Wis Ben 1 karya Bayu Skak, Bagus Bramanti, dan Gea Rexy. (3) Mengidentifikasi nilai-nilai sosial yang terdapat dalam naskah skenario film Yo Wis Ben 1 karya Bayu Skak, Bagus Bramanti, dan Gea Rexy. (4) Menganalisis nilai-nilai sosial yang teridentifikasi di dalam naskah skenario film Yo Wis Ben 1 karya Bayu Skak, Bagus Bramanti, dan Gea Rexy. (5) Membuat kesimpulan.

\section{HASIL DAN PEMBAHASAN}

Berkaca pada kondisi saat ini, era globalisasi di mana teknologi semakin canggih serta banyak kemudahan terdapat di dalamnya, hal ini dapat dirasakan langsung oleh para siswa yang mau tidak mau harus menggunakan teknologi informasi guna mengikuti pembelajaran jarak jauh akibat covid-19. Namun, kemajuan teknologi itu juga memberi dampak negatif terhadap para siswa. Intensitas penggunaan gawai guna mengakses informasi yang cenderung meningkat, lama-kelamaan mengakibatkan penurunan sikap sosial terhadap lingkungan sendiri. Siswa lebih memilih menghabiskan waktu berjam-jam menggunakan teknologi komunikasi dibanding mengobrol dengan orang tua, kakak, adik, sahabat di ruang keluarga maupun sekadar menjalin komunikasi dengan temanteman di dunia maya. Saat ini siswa membutuhkan contoh nyata, sebuah keteladanan yang mengandung nilai sosial agar degradasi nilai sosial siswa akibat covid-19 semakin jauh merosot.

Nilai sosial merupakan salah satu nilai pembangun karya sastra dari unsur ekstrinsik. Penulis merujuk teori dalam buku Badara dan Dinar (2020:10) yang membagi nilai sosial menjadi hubungan sosial, bertanggung jawab terhadap kelompok, kasih sayang, sikap loyal, dan berkorban dan berpartisipasi.

Pada naskah skenario film Yowis Ben 1 nilai sosial masyarakat menjadi nilai yang banyak ditemukan. Nilai sosial pada naskah skenario film Yowis Ben 1 ditinjau dari hubungan sosial, bertanggung jawab terhadap kelompok, kasih sayang, sikap loyal, dan berkorban dan berpartisipasi.

Adapun temuan nilai sosial pada naskah skenario film Yowis Ben 1 yang penulis temukan. Sebanyak 137 temuan nilai sosial yang dibagi menjadi lima bagian sebagai berikut.

Tabel 1 Hasil Penelitian Nilai Sosial yang Muncul dalam Naskah Skenario Film

\begin{tabular}{llc}
\hline No & \multicolumn{1}{c}{$\begin{array}{c}\text { Hubungan Sosial yang } \\
\text { Muncul }\end{array}$} & $\begin{array}{c}\text { Jumlah yang } \\
\text { Muncul }\end{array}$ \\
\hline 1 & Hubungan sosial & 75 \\
\hline 2 & $\begin{array}{l}\text { Bertanggung jawab terhadap } \\
\text { kelompok }\end{array}$ & 20 \\
\hline 3 & Kasih Sayang & 13 \\
\hline 4 & Sikap Royal & 12 \\
\hline 5 & $\begin{array}{l}\text { Berperan dan berpartisipasi } \\
\text { aktif dalam kehidupan sosial }\end{array}$ \\
\hline
\end{tabular}




\section{Hubungan Sosial}

Hubungan sosial dalam masyarakat adalah hal yang tidak dapat terpisahkan. Sebagai salah satu adanya hubungan sosial dalam masyarakat, adanya strata sosial. Dalam masyarakat, strata yang diartikan sebagai pembeda suatu penduduk atau masyarakat ke dalam kelas-kelas secara bertingkat. Pada naskah Yowis Ben 1 hubungan sosial masyarakat muncul karena adanya penilaian dan penghargaan berbagai hal yang berkenaan dengan potensi, kemampuan, keadaan ekonomi, persaingan, dan juga kelebihan fisik.

Penulis menemukan 75 dialog dalam naskah skenario film yang mengandung unsur hubungan sosial dalam masyarakat di dalam skenario film Yowis Ben 1. Naskah skenario yang berlatar masyarakat Jawa Timur dalam lingkungan remaja SMA ini memperlihatkan hubungan sosial sosial berupa penilaian, persaingan antar remaja, potensi diri, dan fisik. Berikut ini dialog naskah skenario yang menjadi temuan penulis berupa penilaian potensi diri.

\section{"Bayu: Ada juga} penggemarku yo?" (kutipan 1) Pada kutipan naskah skenario tersebut menggabarkan sikap Bayu seorang remaja yang ingin membuktikan dirinya di masyarakat tidak menganggap apa yang telah ia capai ada sebuah prestasi di masyarakat. Sikap yang selalu menganggap rendah dan tidak percaya diri. Penilaian terhadap diri membuat lebel diri sendiri dalam kehidupan bermasyarakat. Ada dua proses yang menyebabkan timbulnya pelapisan dalam masyarakat, pertama terjadi dengan dirinya sendiri dan kedua

"Cak Jon: Cewek itu gengsinya gede, kalo nggak percaya lihat aku" (kutipan 2)

Pada kutipan naskah skenario tersebut menggambarkan adanya nasihat paman Bayu bahwa semua perempuan memiliki standar dan kriteria sehingga memiliki tingkat gengsi yang berlebihan. Gender menjadi bentuk lain dari hubungan sosial dalam nilai kehidupan masyarakat. Selain kepemimpinan yang harus dipimpin oleh laki-laki. Partisipasi perempuan dalam hubungan sosial berlaku dalam kehidupan sehari-hari. Selanjutnya juga dipengaruhi oleh kekuasaan.

"Pembeli 2: Dari pada dia, mending aku orang kaya”

(kutipan 3)

Pada naskah skenario tersebut memperlihatkan adaya hubungan sosial yang dilihat dari kekayaan untuk lebih mudah diterima berdasarkan anggapan seseorang. nilai ekonomi (economic stratification) adalah pembedaan seseorang di masyarakat berdasarkan kekuasaan dilihat dari materi. Pada kehidupan keseharian perbedaan itu dilihat dari penghasilan dan kekayaan masyarakat kelas rendah, menengah, dan atas. 
"Doni: Bay-bay udah tau Stevia itu ember, teman-teman aja manggil, hai Stevia cucunya Lambe Turah gitu. Disebarkan puisimu abis kamu!'” (Kutipan 4)

Pada kutipan naskah skenario ini menggambarkan seorang anak laki-laki yang memiliki kepedulian pada temannya. Pada kutipan tersebut memperlihatkan hubungan sosial masyarakat ditunjukkan dari kehidupan sosial masyarakat.

\section{Bertanggung Jawab Terhadap Kelompok}

Dalam kehidupan sosial, remaja memiliki kebutuhan yang besar untuk disukai dan diterima oleh lingkungan teman sebaya ataupun kelompok. Perasaan senang akan muncul pada seorang remaja jika dapat diterima dan sebaliknya akan merasa kecewa jika Tidak diterima, diremehkan, atau dikeluarkan dari kelompok.

Pada naskah skenario film Yowis Ben 1, penulis menemukan 20 dialog dalam naskah skenario yang menunjukkan tanggung jawab terhadap kelompok. Adapun dialog tersebut sebagai berikut.

"Tukang becak: Kok apalagi sih? Sini-sini! (sambil menarik tangan Bayu) Sekarang kamu ceritakan. Kenapa Yowis Ben bubar? (duduk)" (kutipan 5)

Pada kutipan dialog naskah skenario tersebut menggambarkan bahwa dalam kehidupan bermasyarakat sekelompok orang dari suatu komunitas atau kelompok yang sama pasti ada sikap peduli dan keinginan menjadi bagian dari tanggung jawab.

"Bayu: Ini apa sih, kamu yang nulis kok temenku yang dipukul." (kutipan 6)

Pada naskah skenario film ini menggambarkan nilai sosial yang terjadi antarteman sebaya. Pada naskah tersebut menggambarkan hubungan pertemanan seseorang juga dapat dilihat dari bagaimana sikap ia kepada teman. Teman yang dekat adalah teman yang dapat meluapkan apapun termasuk memukul hanya arti dari sebuah ekspresi.

"Pembeli 2: Jangan! Jangan mau nikahi tokoh Bu Jum (ibu Bayu) yang telah berjualan sejak lama dan hanya bekerja sendiri di usianya yang tidak muda." (kutipan 7)

Kedekatannya dengan pembeli yang seumurnya membuat adanya nilai sosial bahwa tolong menolong adalah hal yang penting dalam berteman. Dukungan sosial dalam hubungan antarindividu dibuktikan dan didapatkan sebagai bentuk rasa tanggung jawab yang membuat kita mengatahui kepedulian tehadap teman dalam kehidupan sosial.

"Ibu Bayu: Loh... kok Mlekum lagi.. Assalamualaikum Warahmatullahi Wabarakatuh (mengajari lagi dan Doni menepuk jidatnya)" (kutipan 8)

Pada kutipan naskah skenario ini menggambarkan kehidupan sosial akan ada orang-orang yang melakukan sesuatu yang tidak kita 
harapkan. Dialog tersebut berkaitan dengan tanggung jawab sebagai sebagai orang tua dan muslim dalam mengingatkan. Nilai sosial sebagai tempat memperoleh berbagai informasi mengenai banyak hal. Melalui banyak hal, umpan balik mengenai tindakan yang baik dan kurang baik dapat ditemukan.

"Bayu: Pertama-tama dalam band harus ada personilnya. Aku bersama Doni cuma bawa modal semangat. Nggak masalah anak Rohis atau anak punk..Anak catur atau anak karate. Yakin kalo gini yang daftar pasti banyak!" (kutipan 9)

\section{Kasih Sayang}

Pada naskah skenario film Yowis Ben 1 tidak terlepas dari sikap kasih sayang. Masyarakat merupakan kumpulan individu dan kelompok yang membentuk organisasi sosial yang bersifat kompleks. Dalam kehidupan bermasyarakat terdapat nila-nilai sosial yang berfungsi sebagai aturan dalam berinteraksi dan bertingkah dalam kehidupan Pada naskah skenario film Yowis Ben 1, penulis menemukan 13 dialog dalam naskah skenario yang sikap kasih sayang. Adapun dialog tersebut sebagai berikut.

Tukang becak: Maaf ya, tadi aku kira motornya jahat. (Memeluk erat Bayu) (kutipan 10)

Pada kutipan naskah skenario film Yowis Ben 1 tersebut menyoroti seorang tukang becak bernama
Kamidi yang sangat peduli dengan orang lain. Pada naskah menggambarkan adanya hubungan antar masyarat yang tidak melihat status sosial. Bahkan Kamidi yang tidak tahu bahwa Bayu adalah salah satu personil band yang ia gemari. Dalam nilai sosial, kehidupan masyarakat memiliki lapisan sosial yang memungkinkan terjadinya perpindahan posisi.

"Kartolo: Bu Jum dari pada sendirian saya bantuin, emang gak capek?" (kutipan 11)

Pada kutipan naskah skenario tersebut menggambarkan bahwa dalam kehidupan bermasyarakat terdapat banyak anggapan atau perspektif orang lain tentang seseorang. Anggapan-anggapan tersebutlah yang menjadi hubungan seorang individu dengan masyarakat mengalami perubahan sosial.

Nah kalian ngertikan, tiap hari aku bantuin ibu jualan pecel."oh begitu ya mas" Gara-gara itu aku sama teman-temanku dipanggil... PECEL BOY Aku pengen sih lebih dari itu Tapi tidak apaapa, semua itu demi ibuku. Biar pecelnya laris,biar banyak dapat rezekinya "ya sih mas" (kutipan 12)

Pada dialog naskah skenario tersebut menggambarkan kehidupan sosial yang sangat dekat dengan keluarga. Hubungan dan kasih sayang seorang anak laki-laki dengan ibunya kadang tidak terlihat secara langsung, namun dapat terlihat 
melalui tindakan. Dalam nilai sosial pun demikian, kasih sayang dapat diperlihatkan dengan banyak hal tanpa terkecuali degan tidak membedabedakan. Dalam bersosialisasi tidak boleh membeda-bedakan berdasarkan kasta, tahta, ataupun agama. Masyarakat tidak kaku dalam menghadapi norma-norma sosial yang berlaku dalam masyarakat itu sendiri.

"Bayu: (Melongo, senyumseyum dan jantung berdebar) Ini saatnya untuk unjuk gigi (berbicara dalam hati)" (kutipan 13)

Pada kutipan dialog naskah skenario tersebut menggambarkan masyarakat desa yang saling mengenal satu sama lain sehingga walaupun tidak saling kenal tetapi sangat ramah dan mudah diingat.

"Yayan: Kata guru ngajiku, cara ini efektif. Ku bacakan doa dulu ya (memegang sebuah botol air mineral yang diisi air)" (kutipan 14)

Pada dialog naskah skenario

tersebut menggambarkan bahwa seorang guru memiliki pengaruh besar dalam kehidupan sosial secara individu dan hubungannya dengan masyarakat.

\section{Sikap Loyal}

Pada naskah skenario film Yowis Ben 1 tidak terlepas dari sikaployal. Masyarakat merupakan kumpulan individu dan kelompok yang membentuk organisasi sosial yang bersifat kompleks. Dalam kehidupan bermasyarakat terdapat nila-nilai sosial yang berfungsi sebagai aturan dalam berinteraksi dan bertingkah dalam kehidupan. Sikap loyal menurut kamus besar bahasa Indonesia adalah sebuah kepatuhan atau kesetiaan seseorang. Ada banyak hal yang menyebabkan sikap loyal seseorang terhadap orang lain di dalam kehidupan sosial.

Pada naskah skenario film Yowis Ben 1, penulis menemukan 12 dialog dalam naskah skenario yang mengandung sikap loyal. Adapun dialog tersebut sebagai berikut.

"Tukang becak: Mas Bayu to... mas Bayu ya?" (kutipan15)

Pada dialog naskah skenario tersebut menggambarkan dan memperlihatkan nilai sosial yang erat antara fans fanatik dengan idolanya. Walau pada naskah diceritakan tokoh tukang becak bertemu dengan idolanya yang mengendarai motor butut. Idola yang sangat loyal dengan orang yang diidolakannya dengan mengenal apa saja tentang yang diidolakan.

\section{"Tukang bacak: Aku bukan Cuma nonton Mas, tapi aku penggemarmu! \\ Fans... Fans..." (kutipan 16) \\ Pada kutipan dialog naskah} skenario tersebut menggambarkan dan memperlihatkan hubungan sosial yang terjadi di masyarakat bahwa banyak masyarakat Indonesia yang senang membentuk suatu kelompok untuk memberikan support kepada orang yang mereka anggap pantas dijadikan idola. Pada kehidapan sehari sangat sering terlihat sikap loyal antara idola 
dengan orang yang diidolakan terutama di kalangan remaja. Para orang yang memiliki idola bahkan terkadang melakukan apa pun demi orang yang diidolakannya.

"Tukang becak: Lah, kok member perpus! ya member YWBFCU lah pokoknya sampean gak usah bayar" (kutipan 17)

Pada dialog naskah skenario tersebut memperlihatkan dan menggambarkan seorang idola akan mendapat perlakuan lebih sehingga akan ada hak istiewa seperti menggratiskan sesuatu. Pada kehidupan sehari-hari tidak sedikit masyarakat yang rela menggeluarkan berapa pun uang demi idola yang ia pilih.

\section{Berkorban dan Berpartisipasi di Dalam Kehidupan Sosial}

Pada naskah skenario film

Yowis Ben 1 tidak terlepas dari sikap berkorban dan berpartisipasi di dalam kehidupan sosial. Masyarakat merupakan kumpulan individu dan kelompok yang membentuk organisasi sosial yang bersifat kompleks. Dalam kehidupan bermasyarakat terdapat nila-nilai sosial yang berfungsi sebagai aturan dalam berinteraksi dan bertingkah dalam kehidupan sosial.

Pada naskah skenario film Yowis Ben 1, penulis menemukan 17 dialog dalam naskah skenario yang mengandung sikap berkorban dan berpartisipasi di dalam kehidupan sosial. Adapun dialog tersebut sebagai berikut.

"Cak Jon: Ini orang-orang uzur,dari zaman perjuangan ngejar kakakku aja." (kutipan 18)

Pada dialog naskah skenario tersebut menggambarkan bahwa tindakan ada batasan semangat seseorang dalam mencapai sesuatu walaupun dalam keadaan tua atau umur yang sudah tidak muda lagi. Pada dialog ini sikap berkorban dan berpartisipasi terlihat karena Cak Jon melindungi kakaknya yang diganggu oleh pembeli dan ia juga mengomentari sikap pembeli yang mengganggu kakaknya sehingga terdapat nilai sosial berupa berkorban dan berpartisipasi dalam kehidupan sosial.

"Doni: Dua arah lo Bay, kan saling.. (Menggerakkan jarinya ke arah mata). Apa sih kamu ini? Aku ntar jadi salah tingkah loh. Eh, senyumsenyum...Gila ya" (kutipan 19) Pada kutipan dialog naskah skenario tersebut menggambarkan interaksi dengan teman sebaya yang saling memahami namun kadang lebih mudah mengungkapkan walau menggunakan kata-kata yang tidak tepat. Seperti menggunakan kata 'gila' menjadi hal yang tidak baik namun ketika dengan teman sebaya kata tersebut tidak mengandung hal yang kasar.

Dalam kehidupan sosial sikap berkorban dan berpartisipasi antara teman dapat terlihat saat seseorang sedang mengusahakan suatu hal. 
Seorang teman ataupun keluarga dapat mengambil peran perantara dengan berkorban maupun berpartisipasi.

"Teman Susan 2: Nggak aku nggak mau lihat, Lihat lo followersku 15k." (kutipan 20) Pada kutipan dialog naskah skenario tersebut menggambarkan bahwa memiliki pengikut yang banyak adalah sebuah kehormatan yang tinggi walaupun terkadang didapatkan denan cara membeli. Dalam kehidupan sosial sikap tidak sportif tersebut muncul walau hanya dari media sosial. Namun, sikap tersebut menjadi sikap yang menunjukkan cara seseorang berkorban dalam meraih simpati dari orang lain.

\section{SIMPULAN}

Berdasarkan penelitian tersebut dapat disimpulkan bahwa dalam naskah skenario film Yowis Ben 1 merupakan naskah film mengandung nilai sosial, yaitu hubungan sosial, bertanggung jawab terhadap kelompok, kasih sayang, sikap loyal, berkorban dan berpartisipasi. Pada dialog naskah film ini sangat tercerminkan nilai sosial, seperti eksistensi, potensi, kemampuan, keadaan ekonomi, persaingan, dan juga kelebihan fisik menjadi hal yang sangat dipertimbangkan dalam kehidupan sosial terutama dalam lingkungan siswa remaja dalam naskah film Yowis Ben 1.

Berdasarkan penelitian ini, hal yang menjadi keteladanan bagi siswa dalam interaksi sosial kesehariannya adalah karakter tokoh yang memiliki jiwa sosial. Sebagai makhluk sosial, siswa juga harus memiliki jiwa sosial dalam kehidupan bermasayarakat. Karakter sosial ini harus dimiliki oleh siswa karena manusia tidak bisa hidup sendirian tanpa ada interaksi sesama makhluk sosial lainnya. Keteladanan yang kedua dalam menunjukkan nilai sosial adalah sikap bertanggung jawab yang sedari awal telah dimiliki oleh siswa. Selanjutnya, hubungan individu dengan masyarakat.

Oleh sebab itu, film naskah skenario film Yowis Ben I menjadi panduan sebagai keteladanan dalam merefleksikan kehidupan sosial masyarakat Indonesia khususnya kalangan remaja.

\section{REFERENSI}

Banks, J. A. (2009). Multicultural Education: Characteristics and Goals. In J. A. Banks \& C. A. McGee (Eds.), Multicultural Education: Issues and Perspectives. New York: John Wiley and Sons.

Cahyaningrum, E. S. (2017). Pengembangan Nilai-nilai Karakter Anak Usia Dini melalui Pembiasaan dan Keteladanan. Jurnal Pendidikan Anak, 6(2), 203-213.

Chriszia, D. (2020). Analisis Tokoh Utama dan Nilai Pendidikan Karakter dalam Novel pada Sebuah Kapal Karya NH Dini serta Relevansinya Sebagai Bahan Ajar di SMA. Jurnal Bahasa, Sastra, dan Pengajarannya. 8(2), 338-346.

Febrianto, D., \& Anggraini, P. (2019). Representasi Pewayangan Modern: Kajian Antropologi 
Sastra dalam Novel Rahvayana Aku Lala Padamu karya Sujiwo Tejo. Jentera: Jurnal Kajian Sastra, 8(1), 12-25.

Pebrina, Putri Hana. Jurnal Analisis

Penggunaan Gadget terhadap Kemampuan Interaksi Sosial pada Anak Usia Dini. Universitas Pahlawan Tuanku Tambusai.

Isti. (2017). Komunikasi Media Film Wonderful Life (Pengalaman Sineas Tentang Menentukan Tema Film): Jurnal Komunikasi, 8(1), 33-34

Moleong, J.L. (2014). Metode Penelitian Kualitatif, Edisi Revisi. Bandung: PT Remaja Rosdakarya.

Badara \& Dinar, A. G. (2020). Nilai Pendidikan Karakter dan Nilai Sosial dalam Novel Arok Dedes Karya Pramoedya Ananta Toer Serta Pemanfaatannya Sebagai Bahan Ajar Cerita Sejarah Siswa SMA. Jurnal Bahasa, Sastra, dan Pengajarannya. 8(2), 311324.

Munawwaroh, A. (2019). Keteladanan Sebagai Metode Pendidikan Karakter. Jurnal Penelitian Pendidikan Islam,[SL], 7(2), 141-156.

Novita, et al. (2015). Pengaruh Iklim Keluarga dan Keteladanan Orang Tua terhadap Karakter Remaja Perdesaan. Jurnal Pendidikan Karakter, 5(2), 184-194.

Saptawuryandari, N. (2015). Pandangan Dunia Mochtar Lubis dalam Novel Senja di Jakarta. Aksara, 27(2), 195-206.

Sasmita, A. R. (2021). Kritik sosial dalam cerpen Pelajaran Mengarang Karya Seno Gumira Ajidarma melalui pendekatan Semiotika Pierce. Basastra: Jurnal Bahasa, Sastra, dan Pengajarannya, 9(1). 25-33.

Sularsih, 2015, DIsampaikan oleh Kepala Kantor Perpustakaan Nasional Sri Sularsih dalam acara "Safari Gerakan Nasional Gemar Membaca" di Kulon Progo, Daerah Istimewa Yogyakarta, Rabu, 28 Oktober 2015.

Supranoto, H. (2015). Implementasi Pendidikan Karakter Bangsa dalam Pembelajaran SMA. Jurnal Promosi: Jurnal Pendidikan Ekonomi UM Metro, 3(1), 36-49.

Wening, S. (2012). Pembentukan Karakter Bangsa melalui Pendidikan Nilai. Jurnal Pendidikan Karakter, 2(1), 5566.

Zaqiah, Q. Y., \& Rusdiana, A. (2014). Pendidikan Nilai: Kajian Teori dan Praktik di Sekolah. Bandung: Pustaka Setia.

Nanang M. (2016). Sosiologi Perubahan Sosial Perspektif Klasik, Modern, Posmodern dan Poskolonial, Cet IV, Jakarta: PT. Raja Grafindo Persada. 